\title{
PENGEMBANGAN PROGRAM PEMASARAN KERAJINAN TAPIS KEBUNG TIKHAI MENGGUNAKAN E-COMMERCE PADA UMKM TAPIS KILU ANDAN DI DESA BATU RAJA
}

\author{
Viola De Yusa \\ viola.d.yusa@gmail.com \\ Betty Magdalena \\ betty.magdalena1969@gmail.com
}

INSTITUT INFORMATIKA DAN BISNIS DARMAJAYA

\begin{abstract}
ABSTRAK
Pengembangan Usaha Mikro, Kecil, dan Menengah (UMKM) pada desa Batu Raja khususnya UMKM Tapis Kilu Andan masih memiliki kendala terhadap sistem promosi produk Tapis Kebung Tikhai yang masih sangat sederhana pada UMKM Tapis Kilu Andan. Metode pengabdian yang kami lakukan dengan memberi arahan, mengajarkan teknik-teknik dalam pemasaran secara online melalui media sosial. Kami melakukan optimalisasi marketing di bagian promosi khususnya e-commerce. Dengan adanya pelatihan ini, dapat menambah pengetahuan dan keterampilan UMKM Tapis Kilu Andan dalam memasarkan Tapis Kebung Tikhai yang pada era saat ini sudah serba digitalisasi agar UMKM dapat memasarkan produknya secara lokal, nasional, bahkan internasional.
\end{abstract}

Kata kunci: E-commerce, Tapis Kilu Andan, UMKM,

\section{PENDAHULUAN}

Desa Batu Raja merupakan desa induk di kecamatan Way Lima. Desa Batu Raja terdiri dari 7 (tujuh) dusun dan 14 (empat belas) RT. Di Desa Batu Raja Kecamatan Way Lima terdapat beberapa potensi usaha seperti BUMDes dan UMKM. Namun, hingga saat ini berbagai data menyebut bahwa sebagian besar BUMDes di Desa Batu Raja masih sebatas berdiri dan belum memiliki banyak aktivitas usaha yang menghasilkan. Sebagian lagi belum produktif karena masih sedikitnya pemahaman BUDMdes pada potensi desa terutama sumber daya manusianya.

Di Desa Batu Raja terdapat UMKM yang memproduksi Tapis Kebung Tikhai, maka kami melihat potensi yang ada di
Desa Batu Raja untuk membangkitkan kembali Usaha Mikro Kecil Menengah dengan memanfaatkan sumber daya manusia yang masih berproduktif. Berdasarkan observasi dan pengamatan di lapangan, kami akan mengembangkan UMKM Tapis Kebung Tikhai karena tapis merupakan adat khas Lampung yang dapat dipakai di segala usia. Apabila dilihat dari segi inovasi produk Tapis Kebung Tikhai tersebut belum dikembangkan dengan luas. Selain itu apabila dilihat dari aspek pemasaran belum cukup luas, pembuatan Tapis Kebung Tikhai hanya berdasarkan pemesanan saja dan tidak ready stock. Dengan adanya sumber daya manusia yang cukup ini, kami memanfaatkan keadaan ini untuk mengembangkan inovasi produk segi pemasaran dan pengelolaan sumber daya 
manusianya. Tidak hanya itu, kami juga akan menetapkan pemasaran secara $e$ commerce karena UMKM ini belum menerapkan pemasaran secara online.

Pendirian UMKM Tapis Kebung Tikhai ini sudah berdiri dari tahun 2018 yang didirikan oleh Bapak Irliyanto. UMKM tapis ini memberi nama merk dagangnya, yaitu "Kilu Andan" yang secara harfiah memiliki makna "tolong dijaga" berdasarkan makna tersebut dapat dikatakan bahwa Tapis Kebung Tikhai ini harus dijaga agar selalu terjaga kelestarian khas adat Lampung. Dari jaman dahulu hingga sekarang, pengolahan Tapis Kebung Tikhai masih menggunakan alat tradisional, yaitu dengan manual yang dijahit tangan sehingga proses pengerjaannya berlangsung lama. Penggunaan alat tradisional ini masih bertahan hingga sekarang karena pemilik UMKM tidak ingin menghilangkan khas dari Tapis Kebung Tikhai.

UMKM yang baru dibentuk ini memiliki kendala dari berbagai aspek, terutama pada aspek pemasaran. Pada aspek pemasaran kendala yang dihadapi adalah belum adanya pemasaran produk secara online (e-commerce). E -Commerce ini dibutuhkan oleh suatu UMKM karena $e$ commerce ini digunakan untuk mencapai tujuan pemasaran dalam pasar sasaran suatu UMKM. Penerapan usaha dengan menggunakan media online saat ini sudah menjamur di seluruh dunia, khususnya di Indonesia.

Solusi yang kami tawarkan sesuai dengan permasalahan yang dialami oleh UMKM Tapis Kilu Andan ini, yaitu dengan pemberian pelatihan tentang promosi pemasaran produk tapis mereka dengan menggunakan e-commerce.

\section{METODOLOGI PELAKSANAAN}

Permasalahan prioritas mitra pengabdian adalah pada aspek promosi pemasaran. Pelatihan diberikan kepada kelompok UMKM Tapis Kilu Andan tujuannya agar UMKM nya dapat pengetahuan dan keterampilan dalam bidang pemasaran khususnya untuk promosi produk mereka. Tim pengabdi mempunyai kesepakatan bersama mitra pengabdian, berupa pemberian pelatihan $e$ commerce dalam upaya peningkatan kemampuan melakukan promosi menggunakan aplikasi media sosial yang bermanfaat untuk menunjang kegiatan pemasaran di UMKM Tapis Kilu Andan.

Metode yang digunakan dalam pelatihan e-commerce yang terdiri dari:

1. Program pemasaran dengan Website

2. Membuat akun e-commerce

\section{HASIL DAN LUARAN}

1. Program Pemasaran dengan Website untuk UMKM Tapis Kilu Andan

Saat ini media online adalah wadah terbaik untuk melakukan promo produk dagang yang kita miliki. Untuk itu saya memanfaatkan salah satu media online, yaitu website untuk akses mengembangkan usaha Tapis Kilu Andan. Website adalah suatu halaman website yang saling berhubungan yang umumnya berisikan kumpulan informasi berupa data teks, gambar, animasi, audio, video maupun gabungan dari semuanya yang biasanya dibuat untuk personal, organisasi dan perusahaan. Sesuai dengan definisinya didalam website yang saya buat sudah lengkap berisikan informasi mengenai produk yang ditawarkan. Adanya banyak manfaat yang diperoleh saat memasarkan produk dengan website.

Beberapa manfaat yang dapat diperoleh dari penggunaan website antara lain :

a. Meningkatkan Kredibilitas Usaha Kecil

Hari ini, konsumen semakin banyak menggunakan internet untuk mencari produk atau layanan yang mereka butuhkan.

b. Menghemat Uang

Sebagai fasilitator dari sebuah pemilik usaha kecil, saya berpikir bahwa belum mampu membuat sebuah website yang profesional. Akan tetapi masih banyak opsi 
lain seperti halnya pembuatan website yang sederhana tidak membutuhkan biaya yang besar.

\section{c. Selalu Terhubung Dengan Pelanggan}

Tidak seperti iklan cetak yang cepat menjadi usang, dengan situs website kita dapat memberikan informasi yang senantiasa up-to-date.

\section{d. Mudah Diakses}

Sebuah website bisa diakses oleh pemilik UMKM sendiri dan pelanggan potensial selama 24 jam sehari, 7 hari seminggu, dan 365 hari dalam setahun.

e. Menjangkau Target Pasar Yang Lebih Luas

Menjual produk maupun jasa, website akan selalu menjadi tempat alternatif yang menarik untuk mempromosikannya.

f. Sarana Katalog Produk Dan Jasa (Portofolio)

Dengan memasukkan portofolio atau galeri foto produk, serta testimonial tentang pekerjaan kita, kita dapat menunjukkan apa yang membuat produk kita unik.
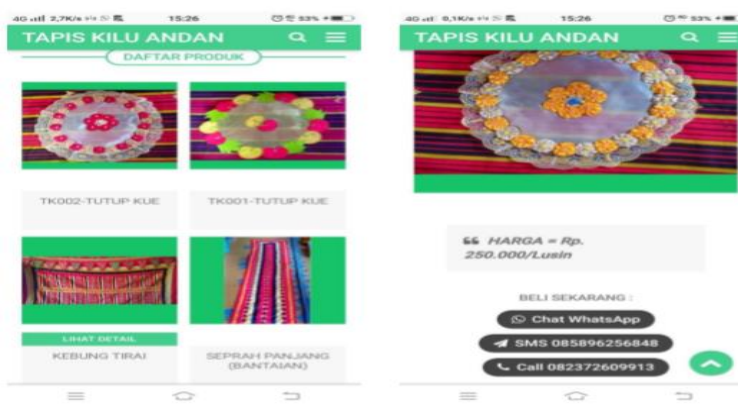

Gambar 1. Tampilan Produk Di Website

Gambar diatas menjelaskan produkproduk yang ditawarkan, harga yang sudah tercantum beserta contact person yang dapat dihubungi ketika calon konsumen berminat untuk membeli. Selain itu jangkauan untuk website ini sangat luas tidak hanya wilayah Lampung akan tetapi ke seluruh Indonesia dapat menjangkaunya.

2. Membuatkan Akun E-commerce Untuk Pemasaran Online Tapis Kilu Andan

UMKM Tapis Kilu Andan milik Bapak Irliyanto merupakan suatu usaha yang cukup menjanjikan. Pemasaran produk Tapis ini dimulai dari warung di sekitar Desa Batu Raja, pasar daerah Way
Lima dan di luar kabupaten ini bisa di kuasai oleh UMKM dengan metode word of mouth sering kita kenal promosi dari mulut kemulut. Namun, di UMKM ini belum adanya suatu Pemasaran secara online sehingga pemasaran produk Tapis tersebut masih terbatas. Maka dalam hal ini saya berencana memasaran produk menggunakan sosial media online dengan menerapkan E-commerce agar pemilik UMKM dapat mencakup pasar yang lebih luas lagi. Tak dapat dipungkiri bahwa media sosial seperti Instagram, Facebook, Youtube, Twitter dan aplikasi messenger seperti Line, Whatsapp dan sebagainya bukanlah hal yang tabu di kalangan masyarakat. Tidak heran bahwa media sosial saat ini digunakan sebagai alternatif bagi setiap pemilik bisnis untuk memasarkan produk atau memperkenalkan bisnisnya dengan cepat. Memasarkan produk yang kita miliki melalui jasa media sosial adalah salah satu strategi pemasaran (Marketing Strategy) yang efektif, mengingat besarnya pengaruh media sosial ini sebagai tempat pengumpulan informasi bagi aspek dan lapisan masyarakat modern saat zaman sekarang.

\section{Pembuatan Media Sosial Instagram}

Tim membuat instagram untuk mengoptimalisasi marketing pada UMKM Tapis Kilu Andan.Kami mulai memasukkan data-data Tapis Kilu Andan meliputi gambar, harga, lokasi, dan penjelasan mengenai Tapis Kilu Andan. Akun Instagram UMKM Tapis Kilu Andan https://www.instagram.com/tapis_kiluanda n/. Tujuan dibuatkan akun media social ini untuk memperluas promosi pemasaran produk mereka.
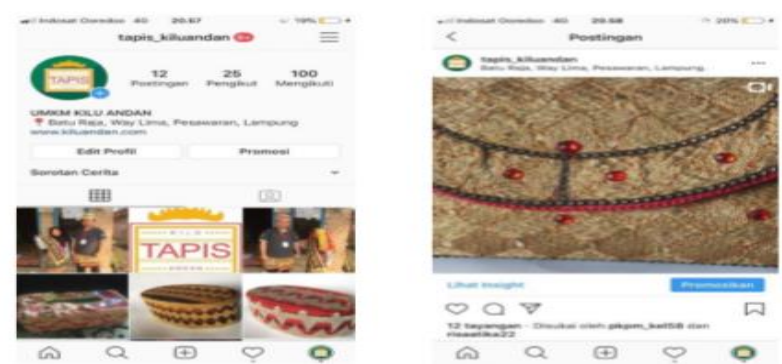

Gambar 2. Akun Instagram UMKM Tapis Kilu Andan 


\section{Menjelaskan Penggunaan Instagram}

Setelah media sosial selesai dibuat, kami memberikan penjelasan cara penggunaan media sosial instagram kepada Bapak Irliyanto. Diharapkan Bapak Irliyanto dapat menjalankan sendiri dalam memasarkan Tapis Kilu Andan dan menyalurkan pengetahuan yang dia miliki kepada beberapa anggota lainnya yang membantu dalam pembuatan produk Tapis Kilu Andan. Dampak dari adanya penggunaan media social terhadap kinerja UMKM Tapis Kilu Andan untuk meluaskan penjualan tapis tersebut ke berbagai daerah baik nasional maupun internasional. Serta mempermudah akses Bapak Irliyanto untuk mendapatkan konsumen dari berbagai penjuru daerah.

\section{KESIMPULAN DAN SARAN}

Pengabdian kepada masyarakat dilaksanakan kepada kelompok UMKM Tapis Kilu Andan. Materi pelatihan berupa pelatihan pembuatan akun e-commerce. Dengan adanya pelatihan ini, dapat menambah pengetahuan dan keterampilan UMKM Tapis Kilu Andan dalam memasarkan Tapis Kebung Tikhai yang pada era saat ini sudah serba digitalisasi agar UMKM bisa memasarkan produknya secara lokal, nasional, bahkan internasional. Setelah dilakukan pengabdian ini diharapkan kedepannya untuk UMKM Tapis Kilu Andan bisa meluaskan pemasarannya melalui shoppee, bukalapak, tokopedia dan lain-lain.

\section{DAFTAR PUSTAKA}

Bambang. (2012). Dasar-Dasar Pembelanjaan (Edisi 4). Yogyakarta: BPFE.

Kotler, P. (2004). Marketing Management Canadiant 11th Edition. Canada: Pearson Education.

Laudon, K. (2013). E-commerce Global Edition. Canada: Pearson Education.
Yusa, D. V., Betty, M. (2015). Pemanfaatan dan Pengembangan Desa Berbasis Web dan Pengembangan Bisnis Budidaya Jamur Tiram Menjadi Bakso Jamur di Pekon Tambah Rejo Kecamatan Gading Rejo Kabupaten Pringsewu. Jurnal Teknologi Informasi dan Bisnis Pengabdian Masyarakat Darmajaya. Vol 01 No 02, Agustus 2015. Hlm 57-73.

Yusa, D.V., Betty, M. (2018). Perancangan Sistem Informasi Desa Berbasis Web dan Pengembangan Bisnis UKM Maya Califa (Manisan Pepaya California) Pada Pekon Negara Batin Kecamatan Kota Agung Barat Kabupaten Tanggamus. Jurnal Dharma Bhakti Ekuitas. Volume 03 No 01, September 2018. Hlm 232239.

Yusa, D.V., Ana, R.J.L. (2018). Pelatihan Pemanfaatan Media Online Sebagai Sarana Pengembangan Usaha Bagi Komunitas Kuliner Sehati. Jurnal Dharma Bhakti Ekuitas. Vol 02 No 02, Maret 2018. Hlm 217-223. 